\title{
Incorporation of thymidine and leucine in the subarctic Pacific: application to estimating bacterial production
}

\author{
David L. Kirchman \\ College of Marine Studies, University of Delaware, Lewes, Delaware 19958, USA
}

\begin{abstract}
This study examines the use of incorporation rates of thymidine (TdR) and leucine (Leu) in order to estimate bacterial production in the oceanic subarctic Pacific. Incorporation rates at different concentrations suggest that isotope dilution is low when $5 \mathrm{nM} \mathrm{TdR}$ is used, but other data indicate at least 3 -fold and 2-fold dilution for $T d R$ and Leu, respectively. The ratio of incorporation into the hot acid insoluble fraction, compared to the cold acid insoluble fraction, is 0.66 for TdR and 0.86 for Leu. Empirical conversion factors were measured in 10 experiments during four 1 mo-long cruises. Conversion factors did not vary systematically and were not affected by additions of organic compounds or ammonium. Average conversion factors were $1.74 \times 10^{18} \mathrm{cells} \mathrm{mol}^{-1}$ of incorporated TdR (SD $=0.89 \times$ $10^{18}$ cells $\mathrm{mol}^{-1}$ ) and $0.108 \times 10^{18} \mathrm{cell}_{5} \mathrm{~mol}^{-1}$ of incorporated Leu ( $\mathrm{SD}=0.085 \times 10^{18} \mathrm{cells} \mathrm{mol}^{-1}$ ). It was possible to estimate 'bottle-less' conversion factors during May 1988 when bacterial numbers increased greatly; in situ bottle-less conversion factors were 1.55 and $0.185 \times 10^{18} \mathrm{cells} \mathrm{mol}^{-1}$ for TdR and Leu, respectively. Estimates of bacterial production based on the TdR and Leu methods agreed within 10 and $25 \%$ for 0 to $40 \mathrm{~m}$ (ca the mixed layer) and 40 to $80 \mathrm{~m}$ (bottom half of the euphotic zone), respectively.
\end{abstract}

\section{INTRODUCTION}

Estimates of biomass production have been instrumental in establishing the importance of heterotrophic bacteria and of dissolved organic matter (DOM) in the pelagic zone of aquatic ecosystems. Bacterial production is usually supported by DOM degradation; particle-bound bacteria are not numerous in many aquatic environments and in most marine systems (Kirchman 1992). Since nearly all DOM is utilized by bacteria (Azam \& Hodson 1977), degradation rates of DOM can be calculated from rates of bacterial production and bacterial growth efficiency (e.g. Kirchman et al. 1991). Degradation rates of the total DOM pool are difficult to measure directly because of the chemical complexity of this pool and because the composition and even total concentration are not well understood (e.g. Williams \& Druffel 1988). The mechanism by which primary production is routed through the DOM pool to bacteria is not well understood (Kirchman et al. 1991), but estimates of bacterial production and conservative growth efficiencies imply that bacteria can consume a large, albeit variable, fraction of primary production $<10$ to $>100 \%$; reviewed by Cole et al. 1988, Ducklow \& Carlson 1992).

Reviews have emphasized that several different methods give roughly equivalent estimates of bacterial biomass production (Cole et al. 1988, Ducklow \& Carlson 1992). The thymidine (TdR) method, however, has been used most frequently since its re-introduction to microbial ecology by Fuhrman \& Azam (1980). The method has been examined extensively in freshwaters, estuaries, and coastal regions. In part because of problems with the TdR method, several investigators have begun to use leucine (Leu) incorporation as a measure of bacterial production. This method, introduced more recently (Kirchman et al. 1985), has not been tested as extensively as the TdR method. Neither method has been examined extensively in the open oceans.

The purpose of this article is to examine some aspects of the TdR and Leu methods and to compare bacterial production estimated by these 2 methods in an open oceanic region, the subarctic Pacific. This study was part of the SUbartic Pacific Ecosystem 
Research (SUPER) program. Previous work has documented that chlorophyll remains relatively constant over time (ca $0.3 \mu \mathrm{g} \mathrm{l}^{-1}$ ) and phytoplankton blooms do not occur in this region, in spite of high inorganic nutrient concentrations (e.g. Wheeler \& Kokkinakis 1990). The subarctic Pacific is an important study area, not only because of this interesting absence of blooms, but also because surfaces waters with high nutrient concentrations like the subarctic Pacific are significant in examining the role of the oceans in buffering changes in atmospheric $\mathrm{CO}_{2}$ (e.g. Sarmiento \& Togg weiller 1984). Elsewhere bacterial biomass and production are compared to analogous phytoplankton parameters (Kirchman unpubl.). Here I show that the TdR and Leu methods give similar estimates of bacterial production.

\section{MATERIALS AND METHODS}

Samples for bacterial abundance and incorporation rates were taken from CTD Niskin bottles with silicone tubing. Nearly all data reported here were from casts taken at noon local time. Samples for bacterial abundance were preserved in $2 \%$ formaldehyde for at most 1 wk before staining with acridine orange and filtration onto Nuclepore filters; cells were enumerated by epifluorescence microscopy (Hobbie et al. 1977).

Incorporation rates of thymidine and leucine. Incorporation of thymidine $\left(\mathrm{TdR} ; 85 \mu \mathrm{Ci} \mathrm{nmol}{ }^{-1}\right)$ and leucine (Leu; $60 \mu \mathrm{Ci} \mathrm{nmol}{ }^{-1}$ ) was measured with samples $(25 \mathrm{ml})$ placed in disposable centrifuge tubes made of clear polystyrene, after the tubes had been rinsed with $0.05 \mathrm{~N} \mathrm{KOH}$, distilled water, and sample water. All isotopes were from NEN Dupont. Samples were incubated for about $2 \mathrm{~h}$ at in situ temperature. Time course experiments demonstrated that incorporation was linear over time for ca $10 \mathrm{~h}$. A killed control was prepared with $5 \%$ trichloroacetic acid (TCA). After incubation, samples were filtered through $0.2 \mu \mathrm{m}$ Nuclepore filters (June 1987) or 0.45 $\mu \mathrm{m}$ Millipore filters (all other cruises). We switched to Millipore filters because their flow rate is faster than that of Nuclepore filters. Also, in direct comparisons, rates determined with Millipore filters were slightly higher $(20 \%)$ than those with Nuclepore filters, even though the blank with Millipore filters is higher (see also Hollibaugh \& Wong 1992). After incubation, the samples were filtered. Filters were rinsed twice with cold $5 \%$ TCA and then cold distilled water before radioassaying.

In June and September 1987, incorporation rates of $\mathrm{TdR}$ and Leu were measured in separate incubations. During all cruises, the concentration of added ${ }^{3} \mathrm{H}-\mathrm{TdR}$ was 5 nM for all routine measurements. In 1987, we used $1 \mathrm{nM}{ }^{3} \mathrm{H}$-leu and $10 \mathrm{nM}$ unlabelled Leu. In 1988 , ${ }^{3} \mathrm{H}$-TdR $(5 \mathrm{nM})$ and ${ }^{14} \mathrm{C}$-Leu $\left(10 \mathrm{nM} ; 0.337 \mu \mathrm{Ci} \mathrm{nmol}{ }^{-1}\right)$ was measured together by the dual-label method (Chin-Leo \& Kirchman 1988).

To test for non-specific incorporation, incorporation of TdR and Leu into the hot and cold TCA insoluble fraction was measured in parallel incubations. The cold TCA procedure is described above. To measure incorporation into the hot TCA fraction, filters were placed into $5 \% \mathrm{TCA}$ and heated to $80^{\circ} \mathrm{C}$ for $15 \mathrm{~min}$. The $5 \%$ TCA was then filtered through Millipore filters. These filters were rinsed twice with cold $5 \%$ TCA and radioassayed along with the original Nuclepore (June) or Millipore (the other 3 months) filters.

To test whether or not $5 \mathrm{nM}$ was the appropriate TdR concentration, the added amount was varied from 1 to $50 \mathrm{nM}{ }^{3} \mathrm{H}-\mathrm{TdR}$ and incorporation was measured as described above.

Conversion factor experiments. To estimate the factors needed to convert TdR and Leu incorporation to rates of bacterial biomass production, water from $20 \mathrm{~m}$ was gravity-filtered through $0.8 \mu \mathrm{m}$ Nuclepore filters and diluted $1: 1$ with water filtered through $0.22 \mu \mathrm{m}$ Millipore filters. This procedure decreases bacterial abundance by about $50 \%$ and nearly totally eliminates bacterivores. Over time (about every $12 \mathrm{~h}$ ), samples for bacterial abundance and incorporation of $\mathrm{TdR}$ and Leu were taken. Conversion factors were estimated by the 'integration approach'; the increase in bacterial abundance (abundance at final time point minus initial value) was divided by incorporation rates integrated over time during the experiment. The error of this conversion factor was estimated from propagation of errors (Bevington 1969) associated with measuring bacterial abundance and incorporation rates.

In some experiments, we added various compounds to the incubations to examine how these compounds affected bacterial growth (Kirchman 1990), ammonium uptake (Kirchman et al. 1990) and conversion factors (this study). The compounds were added (a single addition) to the water prepared as described above and the sample was well mixed. There were no additions to the control incubations. The compounds and their concentrations are presented under 'Results'.

\section{RESULTS}

We sampled 2 stations in the subarctic Pacific, Stn Papa $\left(50^{\circ} \mathrm{N}, 145^{\circ} \mathrm{W}\right)$ and less frequently $\operatorname{Stn} \mathrm{R}\left(53^{\circ} \mathrm{N}\right.$, $155^{\circ} \mathrm{W}$ ) during four 1 mo-long cruises conducted in June and September 1987 and May and August 1988. Stn Papa is near the boundary between the subarctic Pacific water and North Pacific central gyre whereas Stn $\mathrm{R}$ is closer to the dome of the Alaska gyre. The small 
differences in microbial parameters between these 2 stations will not be discussed in detail. Here I examine 2 aspects of the TdR and Leu methods for measuring bacterial production and estimate empirical conversion factors for both methods

\section{Non-specific incorporation}

To examine whether or not TdR was incorporated specifically into DNA, I measured TdR incorporation into the cold TCA insoluble fraction (all macromolecules) and into the hot TCA insoluble fraction (supposedly mostly protein). The ratio of the hot TCA insoluble fraction to the cold TCA insoluble fraction (hot: cold) was nearly 1 for Jun 1987 (SUPER 3), but decreased to $0.51 \pm 0.43$ ( \pm SD) in Sep 1987 (SUPER 4). The hot : cold ratio varied from 0.52 to 0.82 during 1988 (Table 1). These results suggest that much of total ${ }^{3} \mathrm{H}$-TdR incorporation was into protein, although the efficiency of this hot extraction has been questioned (Torréton \& Bouvy 1991).

Table 1. Incorporation of $\left[{ }^{3} \mathrm{H}\right]$-thymidine (TdR), $\left[{ }^{3} \mathrm{H}\right]$-leucine (Leu) (Jun) and $\left[{ }^{14} \mathrm{C}\right.$-leucine (Aug) into hot TCA insoluble vs cold TCA insoluble fractions

\begin{tabular}{|c|c|c|c|}
\hline \multirow[t]{2}{*}{ Date } & \multirow[t]{2}{*}{ Depth (m) } & \multicolumn{2}{|c|}{ Hot/cold } \\
\hline & & $\mathrm{TdR}$ & Leu \\
\hline \multicolumn{4}{|l|}{1987} \\
\hline Jun 7 & 0 & 1.0 & 0.71 \\
\hline Jun 10 & 0 & 1.0 & 1.00 \\
\hline Jun 15 & 0 & 1.0 & 0.94 \\
\hline Jun 21 & 0 & 0.93 & 1.00 \\
\hline Sep 6 & 0 & 0.18 & \\
\hline \multirow[t]{4}{*}{ Sep 20} & 0 & 0.37 & \\
\hline & 20 & 0.33 & \\
\hline & 40 & 0.33 & \\
\hline & 60 & 0.37 & \\
\hline Sep 24 & 0 & 1.00 & \\
\hline \multirow[t]{4}{*}{ Sep 26} & 0 & 0.85 & \\
\hline & 20 & 0.66 & \\
\hline & 60 & 0.46 & \\
\hline & 80 & 0.57 & \\
\hline \multicolumn{4}{|l|}{1988} \\
\hline May 14 & 0 & 0.52 & \\
\hline May 16 & & & 0.90 \\
\hline May 20 & 0 & 0.74 & \\
\hline May 25 & 0 & 0.66 & \\
\hline Aug 7 & 0 & 0.72 & 0.77 \\
\hline Aug 11 & 0 & 0.82 & 0.96 \\
\hline Aug 21 & 0 & 0.73 & 0.63 \\
\hline \multirow[t]{4}{*}{ Aug 24} & 0 & $\underline{0.69}$ & 0.87 \\
\hline & & $\bar{x}=0.66$ & 0.86 \\
\hline & & $s=0.25$ & 0.13 \\
\hline & & $\mathrm{n}=21$ & 9 \\
\hline
\end{tabular}

The hot: cold ratio for ${ }^{3} \mathrm{H}$-Leu or ${ }^{14} \mathrm{C}$-Leu incorporation was high (0.91 in Jun 1987; 0.81 in Aug 1988; Table 1), but lower than that measured for other waters (nearly 1 ; Kirchman et al. 1985). These results suggest that ${ }^{3} \mathrm{H}$-Leu incorporation into the cold TCA fraction overestimated protein synthesis by roughly 10 to $20 \%$, assuming that the hot-cold extractions are effective.

\section{Concentration of added label}

To test whether $5 \mathrm{nM}$ additions of ${ }^{3} \mathrm{H}$-TdR was appropriate, incorporation was measured for ${ }^{3} \mathrm{H}-\mathrm{TdR}$ additions ranging from 1 to $50 \mathrm{nM}$ during Jun and Sep 1987. Incorporation for $<5 \mathrm{nM}$ was always less than that at $5 \mathrm{nM}$; incorporation for $>5 \mathrm{nM}$ was 10 to $46 \%$ higher (Fig. 1). In only one experiment was incorporation at $>5$ nM substantially greater ( $>50 \%$ ) than that at $5 \mathrm{nM}$ (Sep 26; Fig. 1). These results indicate that isotope dilution could lead to underestimating bacterial production when rates are based on $5 \mathrm{nM}$ additions of TdR. But this error was usually small and $5 \mathrm{nM}$ apparently was the most cost-effective and appropriate concentration.

\section{Conversion factors for TdR and Leu}

Conversion factors for TdR and Leu were estimated by comparing incorporation rates with increases in bacterial abundance after minimizing grazing in

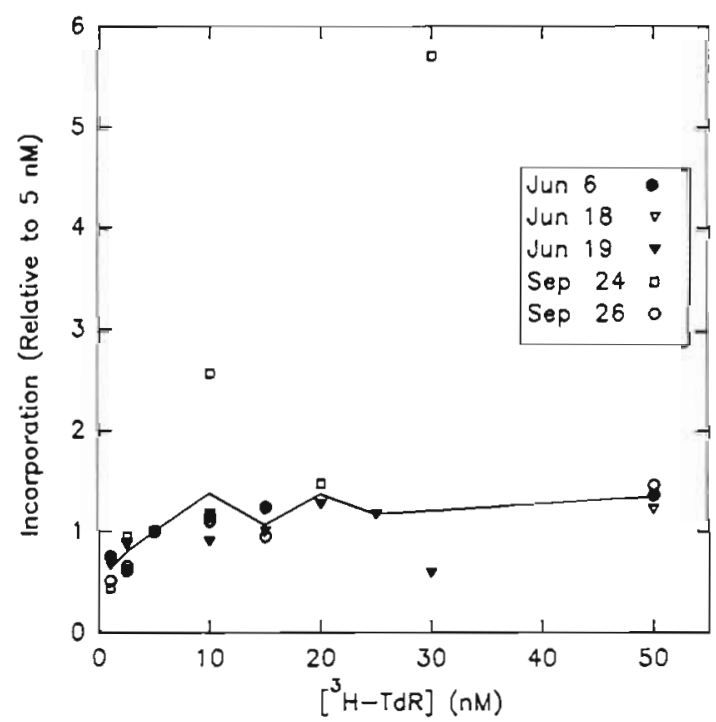

Fig. $1{ }^{3} \mathrm{H}$-Thymidine (TdR) incorporation at different added ${ }^{3} \mathrm{H}-\mathrm{TdR}$ concentrations, normalized for the rate at $5 \mathrm{nM}$. For example, the rate at $10 \mathrm{nM}$ was divided by the rate at $5 \mathrm{nM}$. Data from 2 cruises in 1987. Line is average of all experiments; average at $30 \mathrm{nM}$ not included 
experiments with water from $20 \mathrm{~m}$. The raw data for calculating these conversion factors are given in Table 2. In 17 experiments, conversion factors for TdR varied between 1 and $3.5 \times 10^{18}$ cells $\mathrm{mol}^{-1}$ of $\mathrm{TdR}$ incorporated into the cold TCA insoluble fraction (Table 3). There was no obvious pattern to that variation. It is important to note that additions of organic and inorganic nutrients did not change the conversion factor (however see the freshwater study by Coveney \& Wetzel 1988). The mean conversion factor was $1.74 \times 10^{18}$ cells mol-1 $(\mathrm{SD}=0.88 ; \mathrm{n}=17)$.

In the same experiments, conversion factors for Leu varied between 0.016 and $0.33 \times 10^{18} \mathrm{cells} \mathrm{mol}^{-1}$ of Leu incorporated into the cold TCA fraction (Table 3). As with $\mathrm{TdR}$, there was no systematic trend in the variation, nor did additions affect the conversion factors. The mean conversion factor was $0.108 \times 10^{18} \mathrm{cells} \mathrm{mol}^{-1}$ $(\mathrm{SD}=0.85 ; \mathrm{n}=14)$. The great range (21-fold variation) exaggerates the variation in Leu conversion factors compared with $T \mathrm{dR}$ factors (3.5-fold range), but the coefficient of variation (CV) for Leu factors was still greater than that for TdR (79\% vs $51 \%)$. It is important to note that the CV for all conversion factors was not that much greater than the error in estimating a conversion factor from a single experiment (Table 3).

\section{'Bottle-less' conversion factor}

Bacterial abundance and incorporation rates increased greatly (>3-fold and $>6$-fold, respectively) during May 1988 (SUPER 5). Fig. 2 presents results only from surface samples, but similar changes were observed in values integrated to $40 \mathrm{~m}$ (depth of mixed layer) (Kirchman et al. unpubl.). Incorporation rates peaked on May 24 whereas the maximum bacterial abundance was on May 26 (Fig. 2). The bacterial 'bloom' apparently began to decline after May 26, a few days before we left Stn Papa

The large increase in bacterial abundance and production during May 1988 gives us an opportunity to examine the validity of conversion factors for TdR and

Table 2. Summary of data used to calculate conversion factors for thymidine (TdR) and leucine (Leu) incorporation. Units: initial and integrated abundance (Abund) $=10^{9}$ cells $\mathrm{l}^{-1}$; initial $\mathrm{TdR}$ and Leu: $\mathrm{pM} \mathrm{h}^{-1}$; integrated $\mathrm{TdR}$ and Leu $=\mathrm{pM}$ and $\mathrm{nM}$, respectively; growth rate (from ln change in cell abundance) $=\mathrm{d}^{-1}$

\begin{tabular}{|c|c|c|c|c|c|c|c|c|c|c|}
\hline \multirow[t]{2}{*}{ Date } & \multirow[t]{2}{*}{ Treatment ${ }^{a}$} & \multicolumn{3}{|c|}{ Initia] } & \multicolumn{3}{|c|}{ Integrated } & \multirow{2}{*}{$\begin{array}{l}\text { Growth } \\
\text { rate }\end{array}$} & \multirow[t]{2}{*}{ SE } & \multirow[t]{2}{*}{$\mathrm{N}$} \\
\hline & & Abund. & $\mathrm{TdR}$ & Leu & Abund. & $\mathrm{TdR}$ & Leu* & & & \\
\hline \multicolumn{11}{|l|}{1987} \\
\hline \multirow[t]{2}{*}{ Jun 9} & Control & 0.88 & 0.282 & & 0.57 & 170 & & 0.262 & 0.017 & 6 \\
\hline & DFAA & 0.89 & 0.277 & & 0.96 & 580 & & 0.336 & 0.033 & 6 \\
\hline \multirow[t]{2}{*}{ Jun 21} & Control & 0.45 & 0.176 & 21.0 & 1.26 & 1206 & 48.7 & 0.399 & 0.047 & 9 \\
\hline & DFAA & 0.44 & 0.176 & & 1.32 & 1140 & & 0.417 & 0.047 & \\
\hline Sep 19 & Control & 1.18 & 0.870 & 15.2 & 0.53 & 222 & 9.5 & 0.249 & 0.021 & 6 \\
\hline \multirow[t]{2}{*}{ Sep 25} & Control & 0.64 & 0.28 & 10.4 & 1.48 & 1388 & 50.4 & 0.302 & 0.012 & 10 \\
\hline & Glucose $+\mathrm{NH}_{4}{ }^{+}$ & 0.62 & 0.29 & 10.4 & 2.49 & 2490 & 72.9 & 0.413 & 0.020 & 10 \\
\hline \multirow[t]{2}{*}{ Oct 1} & Control & 0.82 & 2.29 & 51.8 & 2.52 & 744 & 21.9 & 0.380 & 0.048 & 6 \\
\hline & Glucose $^{c}$ & 0.83 & 2.23 & 49.8 & 2.60 & 735 & 22.2 & 0.339 & 0.016 & 6 \\
\hline \multicolumn{11}{|l|}{1988} \\
\hline \multirow[t]{2}{*}{ May 27} & Control & 0.835 & 1.18 & 28.0 & 0.56 & 377 & 20.0 & 0.397 & 0.069 & 6 \\
\hline & Glucose & 0.835 & 1.14 & 27.2 & 0.60 & 733 & 37.3 & 0.236 & 0.096 & 6 \\
\hline \multirow[t]{2}{*}{ Aug 4} & Control & 0.703 & 0.680 & 8.19 & 0.29 & 124 & 2.59 & 0.212 & 0.022 & 4 \\
\hline & RuBPcase $^{d}$ & 0.683 & 0.667 & 17.2 & 0.31 & 126 & 2.45 & 0.231 & 0.012 & 4 \\
\hline \multirow[t]{2}{*}{ Aug 10} & Control & 0.607 & 3.15 & 19.7 & 0.71 & 300 & 7.66 & 0.345 & 0.024 & 4 \\
\hline & RuBPcase & 0.573 & 4.22 & 18.6 & 0.75 & 373 & 8.72 & 0.398 & 0.026 & 4 \\
\hline \multirow[t]{2}{*}{ Aug 19} & Control & 0.706 & 3.53 & 15.9 & 0.10 & 44 & 0.31 & 0.331 & 0.022 & 2 \\
\hline & Alkylamines & 0.706 & 4.78 & 18.0 & 0.06 & 58 & 0.44 & 0.350 & 0.019 & 2 \\
\hline \multicolumn{11}{|c|}{ 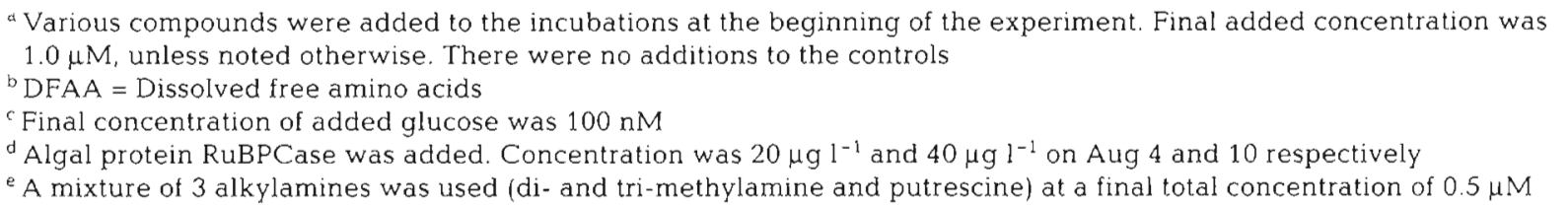 } \\
\hline
\end{tabular}


Table 3. Summary of conversion factor experiments for thymidine (TdR) and leucine (Leu) incorporation in the subarctic Pacific, 1987-1988 (SUPER 3-6). See Table 2 for further details

\begin{tabular}{|c|c|c|c|c|c|c|}
\hline \multirow[t]{2}{*}{ Date } & \multirow[t]{2}{*}{ Treatment } & \multicolumn{4}{|c|}{ Conversion factors $\left(10^{18}\right.$ cells $\left.\mathrm{mol}^{-1}\right)$} & \multirow[t]{2}{*}{$N$} \\
\hline & & $\mathrm{TdR}$ & Error & Leu & Error & \\
\hline \multicolumn{7}{|l|}{1987} \\
\hline Jun 9 & $\begin{array}{l}\text { Control } \\
\text { DFAA }\end{array}$ & $\begin{array}{l}3.35 \\
1.65\end{array}$ & $\begin{array}{l}1.28 \\
0.48\end{array}$ & & & $\begin{array}{l}6 \\
6\end{array}$ \\
\hline Jun 21 & $\begin{array}{l}\text { Control } \\
\text { DFAA }\end{array}$ & $\begin{array}{l}1.04 \\
1.16\end{array}$ & $\begin{array}{l}0.21 \\
0.23\end{array}$ & 0.026 & 0.005 & 9 \\
\hline Sep 19 & Control & 2.38 & 1.15 & 0.180 & 0.027 & 6 \\
\hline Sep 25 & $\begin{array}{l}\text { Control } \\
\text { Glucose }+\mathrm{NH}_{4}{ }^{+}\end{array}$ & $\begin{array}{l}1.06 \\
1.00\end{array}$ & $\begin{array}{l}0.56 \\
0.19\end{array}$ & $\begin{array}{l}0.029 \\
0.034\end{array}$ & $\begin{array}{l}0.004 \\
0.005\end{array}$ & $\begin{array}{l}10 \\
10\end{array}$ \\
\hline Oct 1 & $\begin{array}{l}\text { Control } \\
\text { Glucose }\end{array}$ & $\begin{array}{l}3.39 \\
3.53\end{array}$ & $\begin{array}{l}0.67 \\
0.70\end{array}$ & $\begin{array}{l}0.152 \\
0.154\end{array}$ & $\begin{array}{l}0.021 \\
0.023\end{array}$ & $\begin{array}{l}6 \\
6\end{array}$ \\
\hline \multicolumn{7}{|l|}{1988} \\
\hline May 27 & $\begin{array}{l}\text { Control } \\
\text { Glucose }\end{array}$ & $\begin{array}{l}1.48 \\
0.816\end{array}$ & $\begin{array}{l}0.55 \\
0.307\end{array}$ & $\begin{array}{l}0.028 \\
0.016\end{array}$ & $\begin{array}{l}0.010 \\
0.006\end{array}$ & $\begin{array}{l}6 \\
6\end{array}$ \\
\hline Aug 4 & $\begin{array}{l}\text { Control } \\
\text { RuBPcase }\end{array}$ & $\begin{array}{l}1.75 \\
1.77\end{array}$ & $\begin{array}{l}0.89 \\
0.85\end{array}$ & $\begin{array}{l}0.114 \\
0.126\end{array}$ & $\begin{array}{l}0.058 \\
0.061\end{array}$ & $\begin{array}{l}4 \\
4\end{array}$ \\
\hline Aug 10 & $\begin{array}{l}\text { Control } \\
\text { RuBPcase }\end{array}$ & $\begin{array}{l}1.19 \\
1.02\end{array}$ & $\begin{array}{l}0.33 \\
0.27\end{array}$ & $\begin{array}{l}0.098 \\
0.086\end{array}$ & $\begin{array}{l}0.026 \\
0.023\end{array}$ & $\begin{array}{l}4 \\
4\end{array}$ \\
\hline Aug 19 & $\begin{array}{l}\text { Control } \\
\text { Alkylamines }\end{array}$ & $\begin{array}{l}2.28 \\
1.09 \\
\end{array}$ & $\begin{array}{l}2.73 \\
2.00 \\
\end{array}$ & $\begin{array}{l}0.330 \\
0.142 \\
\end{array}$ & $\begin{array}{l}0.395 \\
0.260 \\
\end{array}$ & $\begin{array}{l}2 \\
2\end{array}$ \\
\hline & $\begin{array}{l}\text { Grand } \bar{x}= \\
\mathrm{SD}= \\
\mathrm{N}= \\
\mathrm{CV}=\end{array}$ & $\begin{array}{c}1.74 \\
0.89 \\
17 \\
51 \%\end{array}$ & & $\begin{array}{c}0.108 \\
0.085 \\
14 \\
79 \%\end{array}$ & & \\
\hline
\end{tabular}

Leu estimated in bottle incubations. We can calculate conversion factors for TdR and Leu during May 1988 by comparing incorporation rates with the increase in bacterial abundance observed in situ, if we assume that grazing was minimal during this month. These 'bottle-less' factors were 1.55 and $0.18 \times 10^{18}$ cells $\mathrm{mol}^{-1}$ for $\mathrm{TdR}$ and Leu, respectively. Although the Leu factor is higher than the average from the bottle experiments, these 'bottle-less' conversion factors are remarkably similar to those calculated from the bottle experiments.

\section{Comparison of thymidine and leucine incorporation rates}

I compared TdR and Leu incorporation rates by linear correlation analysis. Correlation coefficients (r) ranged from 0.37 (Sep 1987, SUPER 4) to 0.98 (Aug 19 to 23, 1988; SUPER 6), which are all statistically significant. The correlation coefficients were lower in 1987 (Table 4), in part because TdR and Leu incorporation were measured separately whereas in
1988 incorporation rates were measured simultaneously in the same incubation with the dual-label method. There was no indication of nonlinearity in graphs of Leu vs TdR incorporation.

Incorporation rates of $\mathrm{TdR}$ and Leu were integrated over depth and converted to rates of biomass production with the mean empirically-derived conversion factors $\left(\mathrm{TdR}=1.74 \times 10^{18}\right.$ cells $\mathrm{mol}^{-1}$; Leu $=0.108 \times$ $10^{18}$ cells $\mathrm{mol}^{-1}$ ). I used the mean conversion factors because the factors did not vary systematically during the cruises and because the uncertainty of a single factor was nearly as large as the variation among the different factors (Table 3 ). Data from both years and all 4 cruises (including Stns Papa and R) were analyzed together. This lumping together of all data ignores the differences observed between TdR and Leu incorporation (Table 4), but avoids problems with determining the proper scale of comparing TdR and Leu (see 'Discussion'). In the mixed layer (0 to $40 \mathrm{~m})$, overall biomass production based on TdR and Leu was virtually the same; the Leu: TdR ratio (now converted to biomass production) was $0.93 \pm 0.09(n=48)$, which is not statistically different from 1.0 (Fig. 3A). For the 


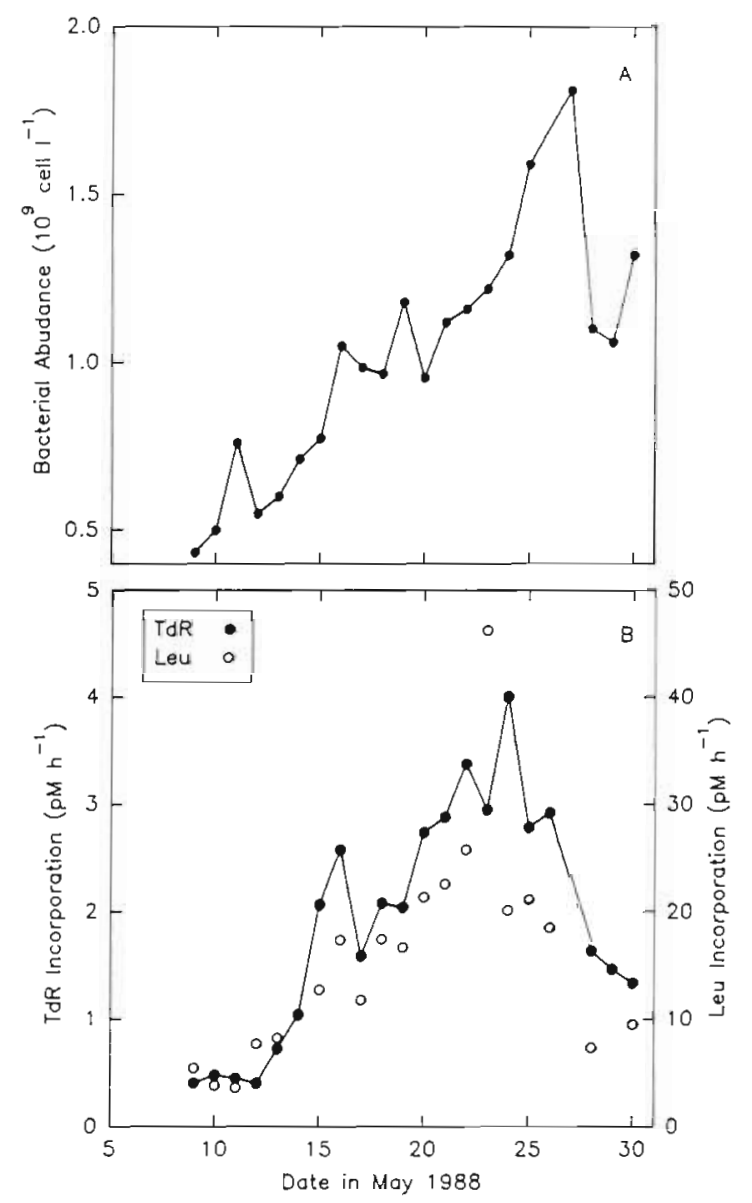

Fig. 2. Bacterial bloom during May 1988. (A) Bacterial abundance; $(B)$ incorporation of ${ }^{3} \mathrm{H}$-thymidine (TdR) and ${ }^{14} \mathrm{C}$-leucine (Leu)

lower layer of the euphotic zone ( 40 to $80 \mathrm{~m}$ ), the Leubased estimate was lower overall than the TdR-based estimate as the ratio was $0.76 \pm 0.08(n=48)$ (Fig. 3B). Since the correlation between TdR and Leu incorporation was not lower for the deeper depths $(40$ to $80 \mathrm{~m})$, this discrepancy in production is probably because our average conversion factors were inappropriate for 40 to $80 \mathrm{~m}$; remember that the conversion factor experiments were conducted with surface waters. Nonetheless, even the $20 \%$ difference between Leu-based and TdR-based production estimates for 40 to $80 \mathrm{~m}$ is very small when other sources of variation are considered.

\section{DISCUSSION}

Heterotrophic bacteria appear to consume roughly $40 \%$ of primary production in open oceans (Ducklow \& Carlson 1992). The percentage for the subarctic Pacific is lower ( 10 to $24 \%$ ) (Kirchman et al. unpubl.) if
Table 4. Statistical comparison of thymidine (TdR) and leucine (Leu) incorporation in the subarctic Pacific, 1987-1988 (SUPER 3-6)

\begin{tabular}{|c|c|c|c|}
\hline Date & Leu : TdR * & $r \cdot$ & $\mathrm{n}$ \\
\hline Jun 1987 & $17.9 \pm 4.0$ & 0.57 & 42 \\
\hline Sep 1987 & $7.8 \pm 3.3$ & 0.37 & 35 \\
\hline May 5-14, 1988 & $20.9 \pm 3.0$ & 0.73 & 44 \\
\hline $15-19$ & $20.6 \pm 1.2$ & 0.93 & 45 \\
\hline $20-25$ & $15.5 \pm 0.8$ & 0.93 & 63 \\
\hline $26-29$ & $13.1 \pm 0.6$ & 0.95 & 45 \\
\hline Aug 4-9, 1988 & $20.2 \pm 1.0$ & 0.92 & 63 \\
\hline $10-18$ & $22.2 \pm 0.8$ & 0.96 & 55 \\
\hline $19-23$ & $14.9 \pm 0.4$ & 0.98 & 41 \\
\hline $24-29$ & $15.3 \pm 1.2$ & 0.79 & 48 \\
\hline \multicolumn{4}{|c|}{$\begin{array}{l}\text { - Leu : TdR estimated from slope of graphs of Leu incor- } \\
\text { poration vs TdR incorporation, } \pm \mathrm{SE} \\
\text {. These correlation coefficients are statistically significan } \\
\text { at the } p<0.05 \text { level (Sep) or at the } p<0.01 \text { level (other } \\
\text { dates) for } n \text { observations, each measured in duplicate } \\
\text { from depth profiles }(0 \text { to } 80 \mathrm{~m} \text { ) }\end{array}$} \\
\hline
\end{tabular}

we use the empirical conversion factors reported here to convert TdR and Leu incorporation rates into bacterial production. These conversion factors are similar to those commonly used and found elsewhere (Table 5). The conversion factors measured in the subarctic Pacific seem to be quite appropriate because they are similar to the 'bottle-less' conversion factors calculated from the in situ change in bacterial abundance and production observed during May 1988. Also, bacterial growth rates independently estimated in dilution cultures (Landry \& Hassett 1982, M. Landry pers.comm.) agree with my estimates of bacterial growth using the empirical conversion factors applied to TdR and Leu incorporation rates. Our understanding of oceanic bacterioplankton, however, is still quite limited, and few studies have examined methodological aspects of measuring bacterial production in open ocean ecosystems (Ducklow \& Hill 1985, Bjørnson \& Kuparinen 1991, Ducklow et al. 1992, Li et al. 1992)

I found that a large fraction of ${ }^{3} \mathrm{H}-\mathrm{TdR}$ was incorporated into the hot TCA-insoluble fraction. High ratios of hot to cold TCA incorporation are usually interpreted as implying high nonspecific incorporation into protein. Torréton \& Bouvy (1991), however, found that hot TCA extractions do not efficiently hydrolyze DNA. This means that incorporation of ${ }^{3} \mathrm{H}-\mathrm{TdR}$ into protein could be overestimated in my experiments.

Addition experiments indicated that isotope dilution for TdR was minimal in the subarctic Pacific. On the other hand, empirical conversion factors for $T d R$ are usually much higher than the theoretical conversion 


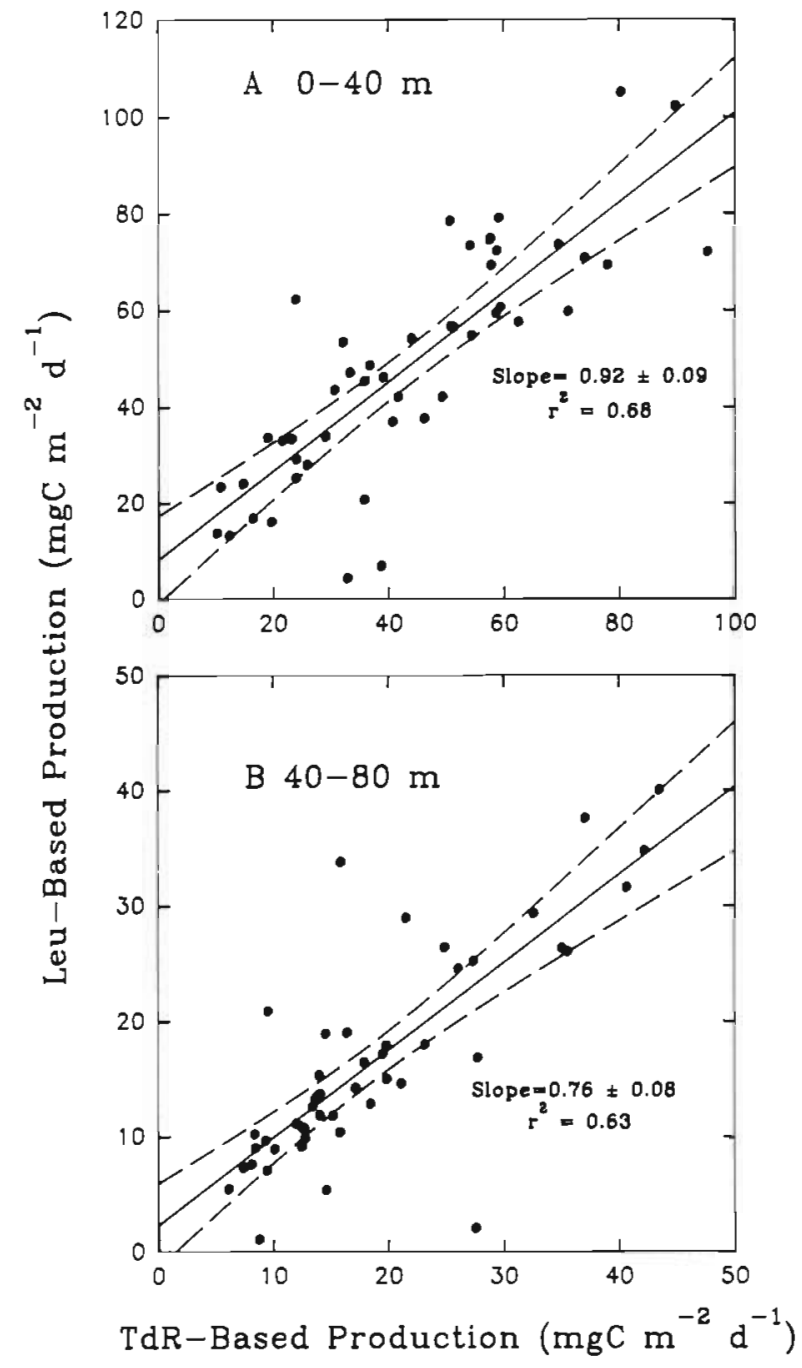

Fig. 3. Comparison of bacterial production estimated from incorporation rates of ${ }^{3} \mathrm{H}$-TdR or Leu $\left({ }^{3} \mathrm{H}\right.$-Leu in $1987,{ }^{14} \mathrm{C}$-Leu in 1988). Mean empirical conversion factors were applied to the entire data set (see Table 3 ). Cell production was converted to biomass production by assuming $20 \mathrm{fgC} \mathrm{cell}^{-1}$.

Linear regression line with $95 \%$ confidence interval

factor in the subarctic Pacific and elsewhere (Table 5). The most likely explanation is that isotope dilution leads to low incorporation of radiolabelled $T d R$ and hence high empirical conversion factors. In addition, although the maximum extracellular Leu concentration was $1.6 \mathrm{nM}$ as measured by high performance liquid chromatography (Simon 1991), much less than the added ${ }^{3} \mathrm{H}$ or ${ }^{14} \mathrm{C}$-Leu (10 or $11 \mathrm{nM}$ ), Simon (1991) directly measured intracellular isotope dilution for Leu in the subarctic Pacific in May 1988 and found it to be $>2$-fold (average of 2.6) when $10 \mathrm{nM}$ Leu was used. These data indicate the uncertainty and problems with measuring isotope dilution. Although attention is now focused on non-specific incorporation (e.g. Holli- baugh \& Wong 1992), I think that isotope dilution is the largest unknown parameter in estimating bacterial production, especially from TdR incorporation. The continuous culture study of Ellenbroek \& Cappenberg (1991) is another indication of the uncertainty caused by TdR isotope dilution.

These methodological details can be problematic if $\mathrm{TdR}$ and Leu incorporation rates are used to estimate DNA and protein synthesis, respectively, which in turn are used to estimate bacterial production. An alternative approach is to use empirical conversion factors. The biochemical and physiological bases for the conversion factor approach are the processes of DNA and protein synthesis. The conversion factor approach, however, simply multiplies incorporation rates by the empirical conversion factors to obtain rates of bacterial production, without considering the details of measuring specifically rates of DNA and protein synthesis. These empirical conversion factors would correct for methodological errors as long as the methodology used for measuring rates in the conversion factor experiments is the same as that for measuring in situ rates. One example is non-specific incorporation. During and after this study, several investigators have reported more accurate and precise rates if the filters are rinsed with ethanol before radioassaying (e.g. Wicks \& Robarts 1987, Hollibaugh \& Wong 1992). My conversion factors would correct for any overestimates due to this nonspecific incorporation, although they do not remove the variability that is reduced by rinsing with ethanol.

Empirical and theoretical conversion factors are similar for Leu but not for TdR (Table 5). Assuming $22 \mathrm{fg}$ bacterial protein cell-1 (cell volume $=0.07 \mathrm{\mu m}^{3}$ ) and $7.3 \mathrm{~mol} \%$ of leucine in bacterial protein (Simon \& Azam 1989), the Leu theoretical conversion factor is $0.082 \times 10^{18}$ cells $\mathrm{mol}^{-1}$ when isotope dilution is zero. The mean empirical conversion factor was 1.34 -fold higher than this theoretical factor. However, note that the theoretical conversion factor is higher than some of the empirical factors listed in Tables $3 \& 5$. In contrast, the empirical factors for TdR are all higher than the theoretical factor (Tables 3 \& 5). One possible explanation is that protein turnover leads to low Leu conversion factors. Some ${ }^{3} \mathrm{H}$-Leu incorporation into protein would not indicate net protein synthesis if there is simultaneous synthesis and degradation of cellular protein, i.e. protein turnover. Protein turnover lowers the empirical conversion factor because the change in bacterial abundance, i.e. net protein synthesis, is low compared with integrated Leu incorporation. The theoretical conversion factor does not account for protein turnover and thus would be higher than the empirical factors. The TdR method, in contrast, should not be affected by protein turnover, unless the TdR rates also include incorporation into protein. 
Table 5. Conversion factors for thymidine (TdR) and leucine (Leu) incorporation in open oceans

\begin{tabular}{|c|c|c|c|}
\hline \multirow[t]{2}{*}{ Environment } & \multicolumn{2}{|c|}{$\begin{array}{l}\text { Conversion factors } \\
\left(10^{18} \text { cells } \mathrm{mol}^{-1}\right)\end{array}$} & \multirow[t]{2}{*}{ Source } \\
\hline & $\mathrm{TdR}$ & Leu & \\
\hline Gulf Stream Ring & 4 & & Ducklow \& Hill (1985) \\
\hline NE Atlantic & $2.6 \pm 0.7$ & $0.18 \pm 0.06^{\mathrm{d}}$ & Ducklow et al. (1992) \\
\hline \multicolumn{4}{|l|}{ NW Atlantic } \\
\hline $40^{\circ} \mathrm{N}$ & 1.0 & 0.055 & Li et al. (1992) \\
\hline $45^{\circ}$ & 2.3 & 0.17 & Li et al. (1992) \\
\hline Southern Ocean & $1.4 \pm 0.9$ & $0.06 \pm 0.01^{b}$ & Bjørnsen \& Kuparinen (1991) \\
\hline Subarctic Pacific & $1.7 \pm 0.9$ & $0.11 \pm 0.08$ & This study \\
\hline Theoretical factors & $0.49^{c}$ & $0.082^{d}$ & \\
\hline \multicolumn{4}{|c|}{${ }^{a}$ Conversion factors calculated by modified derivative method (see Ducklow \& Hill 1985) } \\
\hline \multicolumn{4}{|c|}{$\begin{array}{l}{ }^{b} \text { Conversion factors calculated by cumulative integrative method. TdR factor is the mean and SD of the factors in Table } 3 \\
\text { Leu factor was calculated from data in Tables } 2 \& 3 \text { of Biørnsen \& Kuparinen (1991) }\end{array}$} \\
\hline \multicolumn{4}{|c|}{$\begin{array}{l}{ }^{c} \text { This assumes: (1) no isotope dilution and no DNA turnover; (2) DNA content of } 2.6 \times 10^{-15} \mathrm{~g} \text { cell }{ }^{-1} \text {; (3) TdR content in } \\
\text { DNA of } 25 \% \text {; (4) average molecular weight of the } 4 \text { nucleotides }=318 \text { (Fuhrman \& Azam 1982) }\end{array}$} \\
\hline \multicolumn{4}{|c|}{$\begin{array}{l}{ }^{\mathrm{d}} \text { This assumes: (1) no isotope dilution and no protein turnover; (2) } 22 \times 10^{-15} \mathrm{~g}_{\text {protein }} \text { cell }^{-1} \text {; (3) leucine content in } \\
\text { protein of } 7.3 \% ; \text { (4) molecular weight of leucine }=131 \text { (Simon \& Azam 1989) }\end{array}$} \\
\hline
\end{tabular}

In spite of methodological difficulties, the $T d R$ and Leu methods appear to be giving microbial ecologists reasonable estimates of bacterial production (e.g. Cole et al. 1988, Ducklow \& Carlson 1992). This study, as well as others (see Ducklow \& Carlson 1992) show that the 2 methods work in open oceans. Studies in estuaries first pointed out that TdR and Leu may not give equivalent rates of bacterial production because of unbalanced growth (Kirchman et al. 1985, Chin-Leo \& Kirchman 1990); this has been confirmed for the open ocean (Ducklow et al. unpubl.). These 2 methods, however, do give similar estimates of production when averaged over appropriate time scales, roughly twice the bacterial generation time (Chin-Leo \& Kirchman 1990, Ducklow et al. unpubl.), or integrated with depth (this study). The average production calculated from the 2 methods can vary more smoothly over time than either TdR-based or Leu-based production estimates (Kirchman et al, unpubl.). It remains to be seen if this 'average' production is in fact more useful than examining TdR-based or Leu-based estimates separately.

Finally, perhaps the most interesting and important observation made here concerns the large increase in bacterial abundance in May 1988. This bacterial 'bloom' was not accompanied by any sustained increase in primary production nor phytoplankton biomass (Welschmeyer et al. 1991, Kirchman et al. unpubl.). Temperature increased by $<2$ degrees (from 5.5 to $6.8^{\circ} \mathrm{C}$ ) in surface waters, too little to explain the $>3$-fold increase in incorporation rates and biomass. Because bacterial biomass is about equal to phytoplankton biomass in the subarctic Pacific (Kirchman et al. unpubl.), the May bacterial bloom would seem to have some relationship to the lack of phytoplankton blooms and the control of biological production in the subarctic Pacific. These issues are discussed in more detail elsewhere (Kirchman et al. unpubl.).

Acknowledgements. R.G. Keil conducted many of the experiments reported here. M. Simon helped out in May 1988 and commented on the manuscript. I also acknowledge the support of the SUPER group, especially Charlie Miller for his expert leadership throughout all phases of this project. This study was supported by NSF 8614170 .

\section{LITERATURE CITED}

Azam, F., Hodson, R. E. (1977). Size distribution and activity of marine microheterotrophs. Limnol. Oceanogr. 22: $492-501$

Bevington, P. R. (1969). Data reduction and error analysis for the physical sciences. McGraw Hill, New York

Bjørnsen, P. K., Kuparinen, J. (1991). Determination of bacterioplankton biomass, net production and growth efficiency in the Southern Ocean. Mar. Ecol. Prog. Ser. 71. 185-194

Chin-Leo, G., Kirchman, D. L. (1988). Estimating bacterial production in marine waters from the simultaneous incorporation of thymidine and leucine. Appl environ. Microbiol. 54: 1934-1939

Chin-Leo, G. Kirchman, D. L. (1990). Unbalanced growth in natural assemblages of marine bacterioplankton. Mar. Ecol. Prog. Ser. 63: 1-8

Cole, J. J., Findlay, S., Pace, M. L. (1988). Bacterial production in fresh and saltwater ecosystems: a cross-system overview. Mar. Ecol. Prog. Ser. 43: 1-10 
Coveney, M. F., Wetzel, R. G. (1988). Experimental evaluation of conversion factors for the $\left[{ }^{3} \mathrm{H}\right]$ thymidine incorporation assay of bacterial secondary productivity. Appl. environ. Microbiol. 54: 2018-2026

Ducklow, H. W., Carlson, C. A. (1992). Oceanic bacterial production. Adv. microb. Ecol. (in press)

Ducklow, H. W. Hill, S. M. (1985). Tritiated thymidine incorporation and the growth of heterotrophic bacteria in warm core rings. Limnol. Oceanogr. 30: 260-272

Ducklow, H. W., Kirchman, D. L., Quinby, H. L., Carlson, C. A., Dam, H. G. (1992). Bacterioplankton carbon cycling during the spring bloom in the eastern North Atlantic Ocean. Deep Sea Res. (in press)

Ellenbroek, F. M., Cappenberg, T E. (1991). DNA synthesis and tritiated thymidine incorporation by heterotrophic freshwater bacteria in continuous culture. Appl. environ. Microbiol. 57: 1675-1682

Fuhrman, J. A., Azam, F. (1980). Bacterioplankton secondary production estimates for coastal waters of British Columbia, Antarctica, and California. Appl. environ. Microbiol. 39: 1085-1095

Fuhrman, J. A., Azam, F. (1982). Thymidine incorporation as a measure of heterotrophic bacterioplankton production in marine surface waters: evaluation and field results. Mar Biol. 66: 109-120

Hobbie, J. E., Daley, R. J., Jasper, S. (1977). Use of Nuclepore filters for counting bacteria by fluorescence microscopy. Appl environ. Microbiol. 33: 1225-1228

Hollibaugh, J. T., Wong, P. S. (1992). Ethanol extractable substrate pools and the incorporation and metabolism of thymidine, L-leucine and other low molecular weight substrates by bacterioplankton. Can. J Microbiol. (in press)

Kirchman, D. L. (1990). Limitation of bacterial growth by dissolved organic matter in the subarctic Pacific. Mar. Ecol. Prog. Ser. 62: 47-54

Kirchman, D. L. (1992) Particulate detritus and bacteria in marine environments. In: Ford, T. (ed.) Aquatic microbiology: an ecological approach. Blackwell, Oxford (in press)

Kirchman, D. L., K'nees, E., Hodson, R. E. (1985). Leucine incorporation and its potential as a measure of protein

This article was presented by S. Y. Newell, Sapelo Island, Georgia, USA synthesis by bacteria in natural aquatic systems. Appl. environ. Microbiol. 49: 599-607

Kirchman, D. L., Keil, R. G., Wheeler, P. A. (1990). Carbon limitation of ammonium uptake by heterotrophic bacteria in the subarctic Pacific. Limnol. Oceanogr. 35: 1258-1266

Kirchman, D. L., Suzuki, Y., Garside, G., Ducklow, H. W. (1991). High turnover rates of dissolved organic carbon during a spring phytoplankton bloom. Nature, Lond. 352 : $612-614$

Landry, M., Hassett, R. (1982). Estimating the grazing impact of marine microzooplankton. Mar. Biol. 67: 283-288

Li, W. K. W., Dickie, P. M., Harrison, W. G., Irwin, B. D. (1992). Biomass and production of bacteria and phytoplankton during the spring bloom in the western North Atlantic Ocean. Deep Sea Res. (in press)

Sarmiento, J. L., Toggweiler, J. R. (1984). A new model for the role of oceans in determining atmospheric $P_{\mathrm{CO}_{2}}$. Nature, Lond. 308: 621-624

Simon, M. (1991). Isotope dilution of intracellular amino acids as a tracer of carbon and nitrogen sources of marine planktonic bacteria. Mar. Ecol. Prog. Ser. 74: 295-301

Simon, M., Azam, F. (1989). Protein content and protein synthesis rates of planktonic marine bacteria. Mar. Ecol. Prog. Ser. 51. 201-213

Torréton, J. P., Bouvy, M. (1991). Estimating bacterial DNA synthesis from ${ }^{3} \mathrm{H}$ ]thymidine incorporation: discrepancies among macromolecular extraction procedures. Limnol. Oceanogr. 36: 299-306

Welschmeyer, N., Goericke, R., Strom, S., Peterson, W. (1991). Phytoplankton growth and herbivory in the subarctic Pacific: a chemotaxonomic analysis. Limnol. Oceanogr. 36 : 1631-1649

Wheeler, P. A., Kokkinakis, S. A. (1990). Ammonium recycling limits nitrate use in the oceanic subarctic Pacific. Limnol. Oceanogr. 35: 1267-1278

Wicks, R. J., Robarts, R. D. (1987). The extraction and purification of DNA labelled with | methyl $-{ }^{3} \mathrm{H}$ thymidine in aquatic bacterial production studies. J Plankton Res. 9: $1159-1166$

Williams, P. M., Druffel, E. R. M. (1988). Dissolved organic matter in the ocean: comments on a controversy. Oceanogr. 1: $14-1$ ?

Manuscript first received: December 26, 1991

Revised version accepted: April 15, 1992 